\title{
Rewarding Quality and Innovation: Awards, Charters, and International Standards as Catalysts for Change
}

\author{
Michael E. Milakovich \\ School of Business Administration, University of Miami, Florida, USA \\ memquality@aol.com
}

\begin{abstract}
In the competitive, downsized, and mission-driven global service economy of the early $21^{\text {st }}$ century, all organizations search for models to encourage innovation, measure performance, and raise customer service quality standards. Competition for an award can be a cost effective strategy to identify processes needing improvement, conduct self-assessments, receive objective feedback, and motivate employees to meet higher performance goals. Numerous international, federal, state, local, regional, and private award programs now use similar criteria and methodology to recognize and transfer information about the most effective processes, methods, systems, and results. Awards can advance knowledge about management and organizational learning theory, standardize processes, and assist public, private, and non-profit sector managers in determining which strategies are best suited for their organizations. This paper describes various quality award programs worldwide and reports the preliminary results of an empirical study analyzing the impact of awards on improving service quality in the United States (Survey, 2002).
\end{abstract}

\section{Introduction and Methodology}

All types of organizations are integrating advanced training, new information technologies, and better equipment to meet extraordinary administrative, institutional, and organizational challenges. Reforms are accelerating in many private firms and public agencies, at all levels of government, including the armed services, intelligence and security agencies, departments of health and human services, and several state military reserve units. Public and private service organizations are expanding their missions with limited resources. Similarly, private firms must devote increasingly resources to maintain and improve customer service and security systems.

It is especially difficult for economically hard-pressed firms to integrate human, material, and technical resources necessary to improve relationships and cross-functional (departmental) communication across jurisdictional (geographic) boundaries. To achieve integrated, horizontally-linked, and networked management system reforms, service organizations must demonstrate enhanced capacities for inter and intraorganizational coordination, knowledge management and learning, and performance management. More importantly, they must understand and apply these practices to compare results, exchange information about best practices, improve service delivery, 
integrate human assets with technologies, and standardize performance measures. Organizations seek a common framework to determine if goals are being achieved within the revenue parameters set by private markets or public budgets.

Regardless of the type of reform, employees need motivation and recognition to encourage innovation, improve performance, and sustain management changes. The central research questions raised in this preliminary study are: 1) what choices are available to managers in selecting the most appropriate recognition program? 2) What organizational values do quality awards reward and recognize? 3) How is success measured and what lessons can be publicized and transferred? 4) Are other organizations learning from these innovative benchmark models? 5) Does applying for an award provide the comparative standards, objective assessment, and outside perspective needed to evaluate the performance of internal systems and results? If so, do other organizations regard winners as models for improved performance? 6) Are private or state-sponsored awards being used to recognize, reward and disseminate successful organizational changes? These long-term empirical questions can only be answered with integrated knowledge management systems linking diverse databases across many micro-organizational functions (Agor, 1997; Senge, 1994, 1996; Wimmer, 2002).

This paper presents the conceptual design, preliminary empirical results, and a theoretical basis for an integrated study of how quality awards contribute to overall improvement of productivity. The results are based on a survey of U.S. state quality award offices, conducted in the spring of 2002, which examined the importance of standardizing processes for all organizations. In addition to demographic data, respondents were asked to describe application procedures; the number and types of applications received; the criteria for judging applicants; indicate whether the number of applications was increasing or decreasing; list award criteria and give examples of successful state or local programs; and detail how program successes are publicized and transferred to other companies.

\section{Improving Organizational Performance and Customer Service}

Failure to continuously improve internal processes, human resources, and management systems is a pervasive problem for many service organizations. Many find it difficult, even under the most favorable circumstances, to improve performance with limited resources. Computers, software, and new technologies change so rapidly that equipment, systems, and training protocols become obsolete after just a few months of use. The public service sector is even more vulnerable. In addition to state and local electoral systems, other vital and necessary public sector infrastructure potentially vulnerable to human and material obsolescence include airports, schools, roads, security systems, and public utilities. ${ }^{1}$ As public service or-

1 Until recently, the phrase "public sector innovation" was regarded by many as little more than a bad joke or an oxymoron. The chaos following the 2000 U.S. presidential elections and 2002 primary elections in Florida resulted in part from continued use of obsolete (40year old) technology and failure to invest in new equipment, training, and technologies. Congress has passed legislation and authorized billions of dollars to update equipment, standardized procedures, and improve training to prevent such events from happening again. 
ganizations, governments face unique challenges that may inhibit the adoption of new equipment, systems, training, and technologies. Improving performance is more challenging because: 1) governments experience uneven capacity (and willingness) to measure performance; 2) political interests conflict with multiply preexisting problems of defining citizen and customer needs; 3) private interest groups compete with each other and with government agencies for limited resources; 4) public agencies often find service standards difficult to set and enforce; and 5) outcomes, performance, and results are less tangible and more difficult to measure (deLancer Julnes and Holzer, 2001; Donaldson, 1999; Milakovich, 1998, 2003; Sanderson, 2001). In addition to these factors, a dearth of relevant examples of successful models in specific functions contributes to a pervasive need for "handson", operational, and practical models to guide organizational changes in many service organizations.

During the past decade, numerous service organizations adopted new performance management systems designed to decentralize decision-making authority, empower employees, improve internal management processes, and measure results. Various management styles and techniques encourage higher levels of performance, internal organizational changes, and responsiveness to customers. Many past organizational change efforts also suffered from inconsistent applications and uneven results.

One of the most widely applied approaches, total quality management (TQM), a generic method, focuses on customer (user) satisfaction, participatory management, and a results-orientation. TQM methods and theories often associated with better financial performance and "breakthroughs" in attitudes and motivation among federal government executives, achieve reinvention and results-oriented goals (Hendricks and Singhal, 2001; Milakovich, 1995). Although TQM theories formed the basis for government reinvention in the 1990s, past reforms often spur memories of poor implementation or the resultant downsizing and budget reductions that followed (Douglas and Judge, 2001; Hackman and Wegman, 1995; Milakovich, 1990; Zbaracki, 1998). When appropriately researched, documented, and summarized, comparative methodologies offer administrators detailed "benchmarks" for understanding customers' needs and training employees to meet them. Customers and managers benefit from empirically-based knowledge and theory gained from customer surveys that evaluate the level of service expected and delivered, especially by intelligence, law enforcement and regulatory compliance agencies (Milakovich, 2003).

Applying for an award or an audit certificate provides incentives for employees to improve their processes and services and recognition by outside examiners offers objective evidence of performance gaps. Awards can also serve as a cost effective way to disseminate knowledge about best practices for managing personnel and technology. This eliminates much of the risk from a "trial and error" approach to different improvement strategies and allows less experienced organizations to participate. Organizations that already received awards can use benchmarking for self-promotion and to implement newer more innovative ideas. If effectively implemented, these changes are likely to result in better performance. Most impor- 
tantly, providing incentives, such as awards, charter marks, and audit standards to achieve organizational goals encourages companies to overcome barriers to innovation. $^{2}$

\section{International Quality Awards, Charters, and Standards}

The trend toward decentralized, flexible and results-driven management is accelerating worldwide as more attention is being paid to successful models for managing change. Many companies worldwide have take actions to implement customeroriented and performance-based changes (Sanderson, 2001; Kettl, 2002). Widely used in Asia, Australia, Canada and Europe, various methodologies such as awards, citizen's charters, charter marks, and audit standards help to spread success stories from an expanding number of private companies and governments (Chuan and Soon, 2000; Debia, 2001; Hui and Chaun, 2002; Puay, et.al., 1998; Tummala and Tang, 1996). Globalization of the reinvention effort, with heavy emphasis on electronic government (e-gov) technology, encourages citizen access to information, knowledge management processes, and participation in public decision-making (Fountain, 2001; West, 2001; Wimmer, 2002).

The leading international awards and standards for quality include: the Deming Prize in Japan, the ISO 9000-14000 series, European Quality Awards, and the Malcolm Baldrige National Quality Award (BNQA) in the United States. ${ }^{3}$ These prizes, awards, and audit accreditation programs influenced the creation of numerous state-sponsored U.S. "mini-Baldrige" programs that recognize success at the state and local level as well. Forty-five of the 50 U.S. states, and many local communities, now share similar missions using the BNQA criteria to advance service quality initiatives. In the United States alone, over 1700 private, non-profit, manufacturing and service organizations have received recognition by states and locals awards for service quality and productivity improvements in the past decade (Survey, 2002). In addition, over 50 countries, including Canada, Ireland, Mauritius, Israel, New Zealand, South Africa, Slovenia, Singapore, Sweden, and Taiwan have established national quality awards.

In addition to awards, benchmarking, and e-gov initiatives, citizen charters guarantee specific levels of service and charter marks to recognize agencies for exemplary service (Davison and Grieves, 1996; Van Thiel and Leeuw, 2002). Citizen charters, similar to a "bills of rights" (for airline passengers, consumers, healthcare

2 This creates a "demonstration effect" where "champions" are identified as leaders of specific processes in particular agencies, within various regions. The Director of the California Quality Awards program, for example, identified specific individuals within the state who were known as leaders of the service sector quality movement (Survey, 2002).

3 For details and list of Deming Prize winners, see: <www.deming.org/demingprize/>. www.snqc.org/INFORMATION/QAw.htm. For European Quality Awards, see:www.efqm.org/model_awards/eqa/intro.htm and www.nqi.ca/english/awards.htm; and the Baldrige website <www.nist.gov $>$. 
patients, taxpayers, travelers, etc.) have been enacted during the past two decades in nearly 20 countries, including Australia, Belgium, Canada, Denmark, Finland, France, India, Ireland, Italy, Norway, Portugal, Spain, Singapore, Sweden, as well as governments in the United Kingdom. ${ }^{4}$ At the organizational (micro) level, several steps are being taken to maximize a charter's effectiveness. Charters are bolstered by well-developed systems and procedures and providers must make sure that all employees understand the terms and standards stated in a charter. Charter marks reward excellence, reinforce standards, and raise the level of public service provided. They also improve public service via feedback to applicants.

The Deming Prize is the oldest of the major awards (established in 1950) and many Japanese consider it to be as prestigious as the Academy Awards or the Nobel Prize for quality recognition..$^{5}$ Although less well known in Europe or North America, the Deming Prize influenced the development of quality control and management practices in Asia. The prize recognizes individuals and applicant companies and divisions of companies, including a few non-Japanese companies and service organizations, for their new approaches to total quality control. The ISO 9000-14000 Series, the fastest growing quality assurance system in the world, applies to most types of organizations. Although neither a quality award nor a charter per se, the International Organization for Standards (IOS) audit certification - commonly known as the ISO 9000 through 14000 (for environmental standards) -- series requires the application of many of the same objective criteria and review by outside examiners. (ISO is not an acronym, but the shortened Greek word for equal.) To date, only a few governments are ISO certified and there is a need for more research on its effectiveness in improving the management capacity of service organizations (Chu and Wang, 2001; Lowery, 1998). Nonetheless, the ISO series maintains a commitment to customer service quality improvement and shares many of the same criteria as the Baldrige, Deming, and European quality awards (Puay, et.al., 1998; Tummala and Tang, 1996). Together, the criteria used in these methodologies form a standard multi-national definition of quality processes in most types of organizations (See Table 1). The European Quality Awards, created in 1990 by the European Foundation for Quality Management (EFQM), and in effect since October 1991, spawned many national and regional quality awards throughout Europe and influenced development of ISO 9000 standards. The newest categories for the award were added in 1994: the Public Sector

4 In the United Kingdom, there are over 200 national charters and an estimated 10,000 local charters, all designed to provide better services for citizens. For a detailed and indexed guide to the use of charters, citizen participation, performance standards, charter mark awards, networks, best practices, and how to complain in the U.K., see the excellent Modernizing Public Services Group website at: <www.servicefirst.gov.uk/>.

5 The Union of Japanese Scientists and Engineers (JUSE) evaluates applications and makes the awards to companies and individuals that have achieved high levels of statistical quality control. Japan's leading manufacturers such as Bridgestone, Hitachi, Fuji Photo, Komatsu, Mitsubishi Electric, Nissan, Ricoh, and Toyota among many others have received Deming Prizes. The number of winners each year is unlimited. Any company or individual that achieves a high level of quality and is certified by examiners as meeting rigorous performance standards can be eligible to receive the award. 
Award and the Small and Medium size Enterprises Award. Each applicant is reviewed by a team of Award Assessors, which determines a total score for the application. Based on the final report of the team of assessors, the jury selects the most outstanding organizations for the award.

Table 1. Global Criteria for European and American Quality Awards

Adopted from: Criteria for European Quality Awards and Malcolm Baldrige National Quality Program <http://www.quality.nist.gov/BusinessCriteria.htm>

(1) Leadership: how senior executives guide the organization and how the organization addresses its responsibilities to the public and practices good citizenship;

(2) Strategic Planning: how the organization sets strategic directions and how it determines key action plans;

(3) Human Resource Management: how the organization enables its workforce to develop its full potential and how the workforce is aligned with the organization's objectives;

(4) Information Analysis and Technology: the management, effective use, and analysis of data and information to support key organization processes and the organization's performance management system;

(5) Quality Systems and Processes: how key production/delivery and support processes are designed, managed, and improved;

(6) Customer/Market Focus: how the organization determines requirements and expectations of customers and markets;

(7) Customer/User Satisfaction: documents how the organization meets customers' requirements;

(8) Corporate Governance and Social Responsibility: responds to post-Enron concerns about corporate corruption and social responsibility;

(9) Supplier/Partner Relationships: just-in-time delivery and supply chain management;

(10) Results: the organization's performance and improvement in its key business areas: customer satisfaction, financial and marketplace performance, human resources, supplier and partner performance, and operational performance. For private businesses, this category also examines how the organization performs relative to competition.

Organizations/ companies that demonstrate productivity, results, and the highest levels of customer service are eligible to apply for the Malcolm Baldrige National Quality Award (BNQA), but the number of awards is strictly limited. Although federal agencies are ineligible and there is no specific category for government agencies, the BNQA accepts applications (since 1995) from educational and health care organizations. Every year, the BNQA gives a maximum of two awards in each of five categories (manufacturing, healthcare, education, service, and small business), in contrast to other awards with an unlimited number of winners. Many state and local organizations also encourage recipients to share their success formulas. Seventy-five percent $(75 \%)$ of the states also require winners to showcase their procedures with 
potential applicants (Survey, 2002). The BNQA originally aimed at improving manufacturing quality and productivity by stimulating greater competition (and profits) through the use of quality initiatives. Public recognition of improvements and achievements provide examples for others to benchmark. Winners must publicly share information about quality strategies at a national conference, to guide other organizations and to encourage them to become part of the quality improvement effort. ${ }^{6}$ This requirement is important because learning from the experience of other agencies can stimulate government organizations to become part of the quality process and find effective ways to improve their performance.

As a public-private partnership to reward exemplary and innovative management processes, the BNQA recognizes successful innovation strategies. BNQA criteria acknowledge the importance of results and require winning organizations to prove that their processes have positively affected the quality of outputs. ${ }^{7}$ Although the awards still reinforce the need for private sector international competitiveness in manufacturing, they now emphasize the equally important need to raise the quality of domestic services, especially in education, government, and healthcare.

\subsection{Do Awards Encourage Innovation and Reward Performance?}

Operational design, planning, and policy decisions are based on collection, analysis, and interpretation of objective information. Gathering data is a challenge for most organizations. Achieving goals in high-performance, results-driven, organizations further requires annual strategic planning and performance reviews (Milakovich, 1995; Thompson and Strickland, 2002). Performance management strategies reinforce core values (i.e. collaboration, cost reduction, participation, resultsmeasurement, satisfying external customers, teamwork, etc.) and are used to measure results.

Since the early 1990s, hundreds of quality award programs, created worldwide in the past two decades, now exist. Their recipients, a largely untapped, but increasingly rich, reservoir of detailed information, demonstrate how various organizations successfully change internal processes to measure and meet performance goals. The full global impact of these many awards is too extensive to describe in a single article, but the evolution of several national quality awards has been described elsewhere (Chuan

6 Interview with Myron Tribus, Former Assistant Secretary of Commerce, October 18, 1990. For a complete list of Malcolm Baldrige National Quality Program award recipients, contacts, and profiles see World Wide Web at:

$<$ www.quality.nist.gov/Contacts_Profiles.htm>

7 Since its inception, 58 organizations (37 large and small private manufacturing firms and 21 service organizations) received Baldrige Awards. In 2001, for the first time in the history of the awards, three of the five award winners came from the education category. ${ }^{7}$ In 2002 , SSM Health Care of St. Louis, Missouri became the first such organization to be recognized with a Baldrige Award. In 2003, two other hospitals, Baptist Hospital of Pensacola, Florida, and St. Luke's in Kansas City, Missouri, were recognized. The 2001-2003 awards represent a major change in the mission of the BNQA. 
and Soon, 2000; Dedhia, 2001; Flynn and Saladin, 2001; Hui and Chaun, 2002; Nakhai and Neves, 1994).

\section{Conclusion: A $21^{\text {st }}$ Century Trend or Passing Fad?}

This preliminary study of multi-national recognition programs builds on past research and confirms that most award programs successfully accomplish a majority of what they intend to achieve. All reward organizations for innovation and assist applicants in improving their previous performance levels; some expect this level to be maintained. The future success of quality awards depends on several related factors, including:

- Continued evidence of a positive economic benefit from award winners;

- Commitment from winners to exchange knowledge, share information, and transfer results;

- Shared opportunities for applying knowledge in other types of organizations; and

- Expanded participation by all types of organizations.

The more proof potential applicants have that quality awards can improve the internal efficiency of their organizations, increase profits, and reduce costs, the greater the number of applications. To what extent have awards encouraged other agencies to implement changes? The empirical evidence here is somewhat mixed: two-thirds of the state respondents reported that as of early 2002, applications either increased or remained the same. In states where applications decreased, directors suggested that complexity of award criteria, lack of marketing, and weak regional economic conditions explained most of the decline. These negative factors were overcome in the majority of states by affiliations with corporate sponsors, partnerships with non-profit and private organizations, strong leadership, and volunteer service (Survey, 2002). Encouragingly, despite a sluggish national economy, applications for the Baldrige Awards increased in 2002.

State and local award programs reflect our federalist structure of pluralist decentralized government and are different in many ways: some require payment of examiners fees, others offer cash prizes; some are closely affiliated with the governor's office or corporate sponsors; many are organized as non-profits, and others have multi-tiered awards. However, this preliminary study reveals several common features:

- Most state award programs depend on volunteer support and receive only limited state funding;

- All state awards, and several private and international awards, rely on the Malcolm Baldrige National Quality Award criteria, rules, and application requirements;

- Nearly one-half of the quality award organizations are independently chartered as 501(c)3 non-profit corporations and operate without extensive state budgetary support; 
- Three-quarters $(75 \%)$ of the states require recipients to disseminate results to other organizations;

- In several state, responsible officials, such as directors of quality awards, could identify public officials (champions) who demonstrated success within certain state or local governments and are recognized statewide as quality leaders; and

The common criteria used by all states provide a standardized methodology for comparing one service function to another in diverse regions (Survey, 2002).

As quality recognition becomes the main factor in judging an organization's performance, those that fail to accept the new demands of an increasingly competitive global economy will be less likely to survive. Customer satisfaction is already an obsession for many global service organizations, and most companies already go beyond merely "satisfying" customers to exceeding their expectations. Consequently, awards, benchmarks, charter marks, and international audit standards will most likely play a more significant role by offering credibility in the eyes of citizens, customers, and employees alike. This will be especially important for corporations seeking to regain public confidence and trust. The critical question for future microorganizational research is: have quality awards changed internal organizational processes and systems to provide incentives for individual employees to become more responsive to citizens and supervisors?

Rewarding customer service and performance management, part of this complex process, proves to be a useful way to share best practices, measure results, add value, and achieve quality and productivity goals. Quality awards are an under-utilized resource for organizations committed to improving service quality and performance. They can serve as catalysts for change, identify areas needing improvement, support internal collaboration, motivate everyone to achieve specific goals, and provide learning tools to retain expertise. The competitive challenge and distinction that accompany pursuit of an award, charter mark, or ISO certification can be a significant source of employee motivation and pride. Perhaps most importantly, the data generated by various performance recognition techniques can help to develop theories to assist managers in determining which practices are best suited for their organizations. Awards, benchmarks, citizen charters, and audit standards will never entirely eliminate the differences between the missions of nonprofit, public, or private organizations. They can, however, provide a rich database for assisting businesses and governments in implementing change strategies, developing successful performance measures, and reaching out to all customers being served.

\section{References}

1. Agor, W.H. (1997) "The Measurement, Use, and Development of Intellectual Capital to Increase Public Sector Productivity” Public Personnel Management, Vol. 26, No.2, pp. 175-87. 
2. Chuan, T.K. and Soon, L.C. (2000) "A Detailed Trends Analysis of National Quality Awards World-Wide", Total Quality Management, Vol. 11, No. 8, pp. 1065-1080.

3. Chu, P-Y \& Wang, H-S. (2001) "Benefits, Critical Process Factors, and Optimum Strategies of Successful ISO 9000 Implementation in the Public Sector", Public Performance and Management Review, Vol. 25, No. 1, pp. 105-121.

4. Davison, J. and Grieves, J. (1996) "Why Should Local Government Show An Interest in Service Quality?”, The TQM Magazine, Volume 8, Issue 5, pp. 32-38.

5. Debia, N.S. (2001) "Global Perspectives on Quality", Total Quality Management, Vol. 12, No. 6, pp. 657-668.

6. DeLancer Julnes, P. and Holzer, M. (2001) "Promoting the Utilization of Performance Measures in Public Organizations: An Empirical Study of Factors Affecting Adoption and Implementation", Public Administration Review, Vol. 61, No. 6, pp. 693-708.

7. Donaldson, L. (1999) Performance-Driven Organizational Change. Thousand Oaks, CA: Sage.

8. Douglas, T.J. and W.Q. Judge, (2001) "Total Quality Management Implementation and Competitive Advantage: The Role of Structural Control and Exploration", Academy of Management Executive, Vol. 44, No. 1, pp. 158-177.

9. Flynn, B. \& Saladin, B. (2001) "Further Evidence on the Validity of the Theoretical Models Underlying the Baldrige Criteria" Journal of Operations Management, Vol. 19, No. 6, pp. 617-653.

10. Fountain, J. (2001) Building the Virtual State. Washington, D.C.: Brookings Institution.

11. Hackman, J. \& Wageman, R. (1995) "Total Quality Management: Empirical, Conceptual and Practical Issues" Administrative Science Quarterly, Vol. 40, No.2, pp. 309-342.

12. Holzer, M. and Callahan, K. (1998) Government At Work: Best Practices and Model Programs. Thousand Oaks, CA.: Sage Publications.

13. Hui, KH. and Chaun, T. K. (2002) "Nine Approaches to Organizational Excellence", Journal of Organizational Excellence, Vol. 22, No. 1, pp. 53-65.

14. Kettl, D. (2002) The Global Public Management Revolution: A Report on the Transformation of Governance. Washington, D.C.: The Brookings Institution.

15. Knotts, U. S., L.G Parrish and C. R. Evans (1993) "What Does the U.S. Business Community Really Think about the Baldrige Award?" Quality Progress. Vol. 26, pp. 49-52.

16. Lowery, D. (1999) "ISO 9000: A Certification-Based Methodology for Reinventing the Federal Government", Public Performance and Management Review, Vol. 22, No. 2, pp. 232-250.

17. Milakovich, M. (1990) "Total Quality Management for Public Sector Productivity Improvement", Public Performance and Management Review, Vol. 14, No. 1, pp. 19-32.

18. Milakovich, Michael E. (1995) Improving Service Quality: Achieving High Performance in the Public and Private Sectors. Boca Raton: CRC Press.

19. Milakovich, M. (1998) "The Status of Results-Driven Customer Service Quality in Government”, Journal of Organizational Excellence, Vol. 17, No. 2, pp. 47-54.

20. Milakovich, M. (2003). "Balancing Customer Service, Empowerment, and Performance with Citizenship, Responsiveness and Political Accountability”. International Public Management Review. Vol. 4, No. 1, pp. 61-82.

21. Sanderson, I. (2001) "Performance Management, Evaluation and Learning in 'Modern' Local Government", Public Administration, Vol. 79, No. 2, pp. 297-313.

22. Savas, E.S. (2000) Privatization and Public Policy Partnerships Chatham, N.J: Chatham House.

23. Senge, P.M., et al.(1994) The Fifth Discipline Fieldbook. New York: Doubleday. 
24. Senge, P.M. (1996) "Leading Learning Organizations.” Training \& Development,Vol. 50, No. 12, pp. 36-7.

25. Thompson, A.A. and Strickland, A.J,. (2002) Strategic Management: Concepts and Cases. Burr Ridge, Illinois: McGraw-Hill, 2002.

26. Tummala, V.M. Rao and C.L. Tang (1994) "Strategic Quality Management, Malcolm Baldrige and European Quality Awards and ISO 9000 Certification: Core Concepts and Comparative Analysis", International Journal of Quality and Reliability Management, Vol. 13, No. 4, pp. 8-38.

27. Van Thiel, S. \& Leeuw, F.L. (2002) "The Performance Paradox in the Public Sector", Public Performance and Management Review. Vol. 25, No.3, pp. 267-281.

28. West, D.M. (2001) "Assessing E-Government: The Internet, Democracy, and Service Delivery by State and Federal Governments, 2000." <

29. www.insidepolitics.org/egovtreport00.html>

30. Wimmer, Maria (ed.). (2002) Knowledge Management in e-Government. Vienna, Austria: Trauner Druck.

31. Zbaracki, M. (1998) "The Rhetoric and Reality of Total Quality Management", Administrative Science Quarterly, Vol. 43, No. 3, pp. 602-636. 